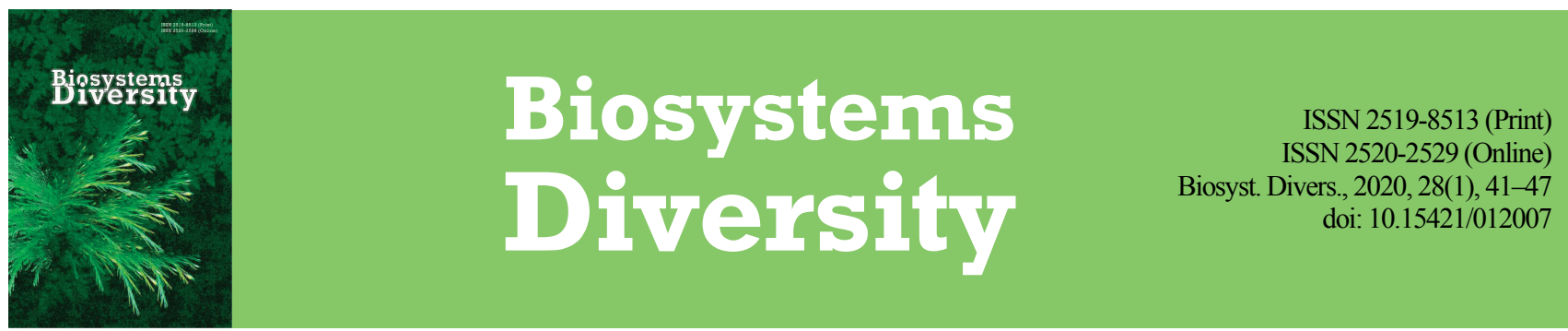

\title{
Staphylinids (Coleoptera, Staphylinidae) of Ukrainian metropolises
}

\author{
A. V. Puchkov*, V. V. Brygadyrenko**, L. I. Faly**, N. A. Komaromi*** \\ *I. I. Schmalhausen Institute of Zoology of National Academy of Sciences of Ukraine, Kyiv, Ukraine \\ **Oles Honchar Dnipro National University, Dnipro, Ukraine \\ ***H. S. Skovoroda Kharkiv National Pedagogical University, Kharkiv, Ukraine
}

Article info

Received 09.02.2020

Received in revised form 05.03 .2020

Accepted 06.03.2020

I. I. Schmalhausen Institute

of Zoology of National Academy

of Sciences of Ukraine,

B. Khmelnytskoho st., 15 ,

Kyiv, 01030, Ukraine

Tel.: +38-095-462-62-23.

E-mail:putchkov@izan.kiev.ua

Oles Honchar Dnipro

National University, Gagarin ave.

72, Dnipro, 49010, Ukraine.

$\mathrm{Tel} \cdot+$ 38-050-93-90-788

E-mail:brigad@ua.fm

H. S. Skovoroda Kharkiv National

Pedagogical University

Alchevskyh st., 29,

Kharkiv, 61000, Ukraine.

E-mail: nkomaromig@gmail.com
Puchkov, A. V., Brygadyrenko, V. V., Faly, L. I., \& Komaromi, N. A. (2020). Staphylinids (Coleoptera, Staphylinidae) of Ukrainian metropolises. Biosystems Diversity, 28(1), 41-47. doi:10.15421/012007

During hundreds of years, in large cities man has been forming a specific urban environment with original species composition of insect communities, including the most diverse group of predatory beetles - Staphylinidae family. Kyiv, Kharkiv, Dnipro are the three most populated cities of Ukraine. In the urban cenoses of these cities, over 140 species from 66 genera of Staphylinidae have been recorded. The total of 69 species (43 genera) were recorded in Kyiv, 67 (39 genera) in Dnipro and 66 (37 genera) in Kharkiv. Among them, , eight species in the catalogue of Palearctic staphylinds had not been previously recorded for Ukraine: Arpedium quadrum Grav., Atheta laticeps Thomson, Medon apicalis Kraatz, Ocalea rivularis Müll., Philonthus salinus Kiesenwetter, Quedius invreae Gridelli, Tasgius pedator Grav. and Xantholinus gallicus Coiffait. By number, common species accounted for 29 in Dnipro, 21 in Kyiv and 19 in Kharkiv. In all the metropolises, two species (Staphylinus caesareus Cederhjelm and Drusilla canaliculata (F.)) were identified as eudominants. Dominants and subdominants comprised 18 25 species. Almost two thirds of the fauna of staphylinids of the cities was classified as rare species. The lowest faunistic similarity was seen between the staphylinids of the urban cenoses of Dnipro and those in Kyiv and Kharkiv (15.3\% and 17.5\%), similarity was higher for Staphylinidae of Kyiv and Kharkiv (36.0\%). Similarity by common species of staphylinids for Kyiv and Kharkiv equaled 73.9\%, 28.2\% for Dnipro and Kyiv and 37.1\% for Dnipro and Kharkiv. The article offers a review of species diversity, number and ecological structure (biotopic confinedness, hygrothermal preference) of typical species of staphylinids in different urban cenoses of Kharkiv. Differences in qualitative-quantitative and ecological structures of staphylinids are related to the diversity of the conditions in a particular urban cenoses. The commonest representatives of the family in the metropolises were polytopic mesophilous carnivorous species.

Keywords: species composition; ecological structure of communities; rove beetles; urban cenoses; cities; Ukraine.

\section{Introduction}

The most important representatives of natural and transformed biocoenoses are insects. The cities are not exceptions, especially large ones, in which the urban cenoses are the specific environment for many species of Insecta. Among them, the largest order is beetles (Coleoptera), in which staphylinids (Coleoptera, Staphylinidae) is one of the dominating groups both by species composition and abundance. Fauna and biology of staphylinids, especially in natural ecosystems are subjects of numerous studies, including for the territory of Ukraine (Frank \& Ahn Kee-Jeong, 2011; Nasira et al., 2012; Grebennikov \& Anikin, 2015; Parmain et al., 2015; Kanao et al., 2016; Betz et al., 2018; Lutska, 2019; Salnitska \& Solodovnikov, 2019). By contrast to some other beetles (for example Carabidae), there are not many studies on staphylinids in urban landscapes of Europe; the data on them are poor even at faunistic level. More or less detailed studies of the species composition of staphylinids, their abundance in green zones were undertaken for a number of cities of Central Europe (Klausnitzer et al., 1980, 1982; Klausnitzer, 1986, 1990; Franzen, 1992a, 1992b; Magura et al., 2013), Belarus (Molodova, 1991; Halinouski \& Shauro, 2007) and Russia (Shulaev \& Bogdanov, 2008), with 30-140 species recorded for each. These studies mainly focused on the main issues of faunistics, and to a lesser extent - ecological peculiarities and biotopic distribution of species. However, these studies allowed interesting data to be obtained and preliminary evaluation to be made of Staphylinidae in the conditions of urban cenoses.

The available studies on staphylinids of Ukraine (also by contrast to well studied species of ground beetles) are fragmented. They superficially describe some structures of the communities in particular cities - Kyiv, Dnipro, Kharkiv (Dekhtyartva, 2002; Faly \& Glotov, 2012; Petrenko,
2005; Nazarenko \& Petrenko, 2007; Komaromi et al., 2018). Nonetheless, in general the staphylinids in urban cenoses of Ukraine are studied somewhat better than for example lamellicorn beetles (Scarabaeidoidea) and clown beetles (Histeridae) (Putchkov et al., 2017, 2018). Furthermore, the comparative analysis of the fauna in different cities of Ukraine is available only for some ground beetles (Putchkov et al., 2019), and is completely absent for other species of beetles. Therefore, better understanding of the peculiarities of formation of the staphylinid fauna in the conditions of a metropolis requires not only in-depth analysis of ecologic-faunistic structure of communities of this group of beetles within one city, but also comparative surveys of the family in several localities.

The objective of our study was elaboration of species composition of Staphylinidae in urban cenoses of three cities of Ukraine, with analysis of peculiarities of their fauna, characterization of the ecological structure of their communities.

\section{Material and methods}

The basis of the study was formed by our own collections and observations in the cities Dnipro (2010-2015), Kyiv and Kharkiv (2017-2019) during surveys on the species composition and ecological structure of beetle communities which occur in the herpetobium ( litter fauna) of the cities' main green zones. In Kharkiv the records were obtained from city parks, Kharkiv Forest Park, plantations in the central part of the city (Pushkinskaia street, the territory of the Scientific and Research Center of Forestry and Agro-Forest Melioration named after H. N. Vysotsky), plantations in the peripheral parts of the city (territory of the Botanical Garden of the H. S. Skovoroda Kharkiv National Pedagogic University and partly the housing complex Saltovka), gardens of private houses on the outskirts 2020, 28(1) 
of Kharkiv (Oleksiivka). Their characteristic is completely presented in studies published earlier (Fedyay et al., 2018; Komaromi et al., 2018; Putchkov et al., 2019). In Dnipro the insects were collected in the territories of some of the city's parks (Park named after 40 Years of the Liberation of Dnipropetrovsk, Yuri Gagarin Park, Volodia Dubinin Park), Botanical Garden of the Oles Honchar Dnipro National University, and in the ravines located within the city (Tunnelna, Aeroportovska Ravines), in the areas of the city's periphery - in the woodland along the Pobeda Embankment, and forests around the city (Voloske village, DniprovskoOrilsky Nature Reserve). Characteristic of certain areas are given in the works of the authors (Faly, 2014; Faly \& Brygadyrenko, 2014, 2015; Brygadyrenko \& Korolev, 2015; Brygadyrenko, 2016; Faly et al., 2017). In addition, for faunistic comparison, collections of staphylinids from separate urboecosystems of Kyiv were used (Petrenko, 2005; Nazarenko \& Petrenko, 2007).

During the studies, we mainly used soil pit-fall traps (plastic cups of $200 \mathrm{~mL}$ capacity filled with $10 \%$ solution of acetic acid). The extractions of the material were taken with $10-15$ days intervals since late April to early November. In each biotope, 10-30 traps were set. Additionally, the beetles were recorded and collected on itineraries around the city. For the evaluation of the species similarity of insects from certain areas, we used Jaccard coefficients of species similarity presented as a percentage, and the number was determined using absolute values (total number of caught beetles), and the number of specimens by 10-catching days or 10 traps a season.

By the level of number (taking into consideration the captured specimens - around 2,000-5,000 in each city), four groups were distinguished: eudominant (or abundant, over $10 \%$ of the total number of caught beetles), common (or dominant, 1-10\%), subdominant (or not common, but constantly found, $0.3-1.0 \%$ ), rare $(0.1-0.3 \%$ ) and occasional (or singular, one to five specimens throughout the period of collecting). In smaller extractions (for separate urban cenoses where the total number of caught beetles equaled $1,500 \mathrm{spec}$.), eudominants were recognized as the species the share of which exceeded $20 \%$ of the total number of beetles in the area, dominants $-3.0-19.9 \%$, subdominants $-0.5-2.9 \%$, rare -0.2 $0.5 \%$, occasional-less than $0.2 \%$. The first three groups (regardless of the number of selection) in the study were considered as common for one or another biocenosis. For urban lawns and garden squares affected by heavy recreational load (mainly trampling), the quantitative characteristics are not provided (but discussed in the text of the study) due to the very low number of all beetle families in them.

The ecological characteristic of staphylinids is given not only for typical species (mainly on the example of their abundance in the urban cenoses of Kharkiv as the most surveyed territory) on the basis of both our observations and a whole range of data from the literature (Tikhomirova, 1973; Klausnitzer et al., 1982; Klausnitzer, 1990; Petrenko, 2005; Nazarenko \& Petrenko, 2007; Shulaev \& Bogdanov, 2008), as well as consultations with the Dr. Ph. A. A. Petrenko (Kyiv).

Classification of the superfamily is given in accordance with the catalogue of the staphylinid beetles of the Palearctic (Schülke \& Smetana, 2015), but the lists of species in the tables are given alphabetically.

\section{Results and discussion}

Rove beetles (Coleoptera, Staphylinidae), noted in the epigeal habitat of urban cenoses, are one of the dominant groups of coleopterans. In the territory of Kharkiv, according to the records of epigeal beetles in 20172018 , in taxonomical relation they were inferior only to ground beetles (Carabidae, around 90 species) and snout beetles (Curculionidae, 53 species) (Komaromi et al., 2018), but taking into account data of 2019- only to carabids. For the abundance, we observed similar tendency: the total share of staphylinids equaled $10-30 \%$ of the total number of beetles of the epigeal habitat of one or another urban cenoses (compared with 30-35\% for snout beetles and $12-18 \%$ for ground beetles).

In total, in the studies of urban cenoses of Kharkiv, Dnipro and Kyiv, according to our own and the literature data (Dekhtyareva, 2002; Petrenko, 2005; Nazarenko \& Petrenko, 2007), over 140 species from 66 genera were recorded (Table 1). However, actual data are given for 126 species, because separate representatives of genera Aleochara, Anotylus, Atheta, Bledius, Carpelimus, Gyrohypnus, Heterothops, Ichnosoma, Lathrobium,
Mycetophorus, Omalium, Oxypoda, Plathystethus, Quedius, Sepedophilus, Stenus, Tasgius, Xantholinus and especially some representatives of the Aleocharinae subfamily have not been identified so far. Therefore, we can confidently presume that the list of staphylinids of the surveyed metropolises in total will increase to $150-160$ species. The largest genus was Philonthus, within which 17 species were observed. Genera Anotylus and Xantholinus were represented by six species each, whereas Tachyporus five. Among Aleochara, Bledius, Lathrobium, Quedius, Sepedophilus and Tasgius, 4 species were recorded. Five more genera (Atheta, Gabrius, Ocypus, Rugilis, Stenus) were represented by three, and the rest - one-two species. Taking into account that a number of species are so far identified only at the level of genus and even subfamily, the species composition of staphylinids in each metropolis can increase by no less than $20 \%$. Such diversity is not a surprise, taking into account the size of the family, broad ranges and high ecological flexibility of many species. For example, for for Kazan alone (Russia), 141 species of staphylinids have been recorded (Shulaev \& Bogdanov, 2008).

Table 1

Species composition of staphylinids in three metropolises of Ukraine

\begin{tabular}{|c|c|c|c|}
\hline Genera, species & Kyiv & Kharkiv & Dnipro \\
\hline Achenium depressum (Gravenhorst, 1802) & - & - & 1 \\
\hline Acidota cruentata Mannerheim, 1830 & 1 & - & - \\
\hline Aleochara bipustulata (Linnaeri, 1761) & - & 1 & 1 \\
\hline A. curtula (Goeze, 1777) & - & - & 2 \\
\hline A. laevigata Gyllenhal, 1810 & - & 2 & - \\
\hline Aleocharasp. & & 1 & 1 \\
\hline Aleocharinae gen. sp. & 2 & 2 & 2 \\
\hline Anotylus insecatus Gravenhorst, 1806 & - & 2 & - \\
\hline A. inustus Gravenhorst, 1806 & & 1 & \\
\hline A. rugifrons Hochhuth, 1849 & - & 1 & - \\
\hline A. rugosus (Fabricius, 1775) & & 1 & 1 \\
\hline A. sculpturatus (Gravenhorst, 1806) & 1 & - & - \\
\hline Anotylus sp. & 1 & 1 & 1 \\
\hline Arpedium quadrum (Gravenhorst, 1806)* & 1 & - & - \\
\hline Astenus immaculatus Stephens, 1833 & - & - & 1 \\
\hline A. procerus (Gravenhorst, 1806) & 1 & 1 & - \\
\hline Astrapaeus ulmi Rossi, 1790 & - & 1 & - \\
\hline Atheta laticeps (Thomson, 1856)* & - & - & 1 \\
\hline A. parca (Mulsant \& Rey, 1873)** & - & - & 1 \\
\hline Atheta sp. & 1 & 1 & 1 \\
\hline Bledius furcatus (Olivier, 1811)** & - & 1 & - \\
\hline B. procerulus Erichson, $1840^{* *}$ & 1 & - & - \\
\hline B. tricornis (Herbst, 1784) & - & - & 2 \\
\hline B. unicornis (Germar, 1825)** & - & 1 & - \\
\hline Bledius sp. & - & - & 1 \\
\hline Brundinia marina (Mulsant et Rey,1853) & - & - & 1 \\
\hline Bryoporus cernuus (Gravenhorst, 1806) & 1 & - & - \\
\hline Carpelimus sp. & 1 & - & 1 \\
\hline Cilea silphoides (Linnaeus, 1767) & 1 & - & - \\
\hline Dacrila fallax (Kraatz, 1856)** & - & - & 1 \\
\hline Dinaraea aequata (Erichson, 1837) & - & - & 1 \\
\hline D. angustula (Gyllenhal, 1810) & - & - & 1 \\
\hline Drusilla canaliculata (Fabricius, 1787) & 3 & 3 & 3 \\
\hline Emus hirtus (Linnaeus, 1758) & 1 & 1 & - \\
\hline Falagria sulcatula (Gravenhorst, 1806) & 2 & - & 2 \\
\hline Falagrioma thoracica (Stephens, 1832)** & 1 & - & - \\
\hline Gabrius nigritulus (Gravenhorst, 1802) & - & - & 1 \\
\hline G. osseticus (Kolenati, 1846) & 2 & 2 & - \\
\hline G. suffragani Joy, 1913 & - & - & 1 \\
\hline Gabronthus thermarum Aubé, 1850 & - & 1 & - \\
\hline Gauropterus fulgidus (Fabricius, 1787) & - & 1 & \\
\hline Gymnusa brevicollis (Paykall, 1800) & 1 & - & \\
\hline Gyrohypnus fracticornis (Muller, 1776) & 1 & - & - \\
\hline Gabrius sp. & 1 & 1 & - \\
\hline Heterothops sp. & - & 1 & - \\
\hline Hypnogyra angularis (Ganglbauer, 1895) & 1 & - & - \\
\hline Ilyobates nigricollis (Paykull, 1800) & 2 & - & - \\
\hline Ischnosoma splendidus (Gravenhorst, 1806) & 1 & - & - \\
\hline Ichnosoma sp. & - & 1 & - \\
\hline Lathrobium brunnipes (Fabricius, 1792) & 1 & - & - \\
\hline L. flavipes Hochhuth, $1851^{* *}$ & - & - & 2 \\
\hline L. fulvipenne (Gravenhorst, 1806) & - & - & 1 \\
\hline Lathrobium sp. & 1 & 1 & 1 \\
\hline Leptacinus batychrus (Gyllenhal, 1827) & - & - & 1 \\
\hline Leptobium gracile (Gravenhorst, 1802) & - & - & 1 \\
\hline Leptophius flavocinctus Hochhuth, 1849 & - & 1 & - \\
\hline Lordithon exoletus (Erichson, 1839) & 1 & - & - \\
\hline
\end{tabular}




\begin{tabular}{|c|c|c|c|}
\hline Genera, species & Kyiv & Kharkiv & Dnipro \\
\hline L. lunulatus (Linnaeus, 1760) & 2 & - & - \\
\hline Medon apicalis (Kraatz, 1857)* & - & - & 2 \\
\hline Mycetophorus sp. & 1 & 1 & - \\
\hline Myrmoecia plicata (Erichson, 1837) & 1 & - & - \\
\hline Nehemitropia lividipennis (Mannerheim, 1830) & - & - & 1 \\
\hline Neobisnius procerulus (Gravenhorst, 1806) & - & - & 1 \\
\hline Ocalea rivularis Muller, $1851^{*}$ & 1 & - & - \\
\hline Ochthephilum fracticorne (Paykull, 1800) & - & - & 2 \\
\hline Ocypus brunnipes Fabricius, 1781 & - & 2 & - \\
\hline O. nitens (Schrank, 1781) & 3 & 3 & 2 \\
\hline O. picipennis Fabricius, 1781 & 1 & 1 & - \\
\hline Olophrum assimile (Paykull, 1800) & 2 & 2 & - \\
\hline Omalium rivulare (Paykull, 1789) & 1 & 2 & - \\
\hline Omalium sp. & 1 & 1 & - \\
\hline Ontholestes murinus Linnaeus, 1758 & - & 1 & - \\
\hline O. tessellatus (Geoffroy, 1785) & - & - & 2 \\
\hline Othius punctulatus (Goeze, 1777) & 2 & 1 & 2 \\
\hline Oxypoda acuminata (Stephens, 1832) & 1 & - & - \\
\hline Oxypoda sp. & 1 & 2 & - \\
\hline Oxyporus rufus (Linnaeus, 1758) & - & 1 & - \\
\hline Oxytelus piceus (Linnaeus, 1767) & - & - & 1 \\
\hline Paederus fuscipes Curtis, 1826 & 1 & 1 & 2 \\
\hline P. littoralis Gravenhorst, 1802 & 2 & 1 & - \\
\hline Philonthus carbonarius (Gravenhorst, 1802) & 1 & 1 & 2 \\
\hline Ph. caucasicus Nordmann, 1837 & - & - & 1 \\
\hline Ph. cognatus Stephens, 1832 & - & 1 & - \\
\hline Ph. decorus (Gravenhorst, 1802) & 2 & 2 & - \\
\hline Ph. fumarius (Gravenhorst, 1806) & - & - & 2 \\
\hline Ph. intermedius (Lacordaire, 1835) & - & - & 3 \\
\hline Ph. laminatus (Creutzer, 1799) & - & 1 & - \\
\hline Ph. lepidus (Gravenhorst, 1802) & 1 & 1 & - \\
\hline Ph. politus Linnaeus, 1758 & & 1 & - \\
\hline Ph. punctus (Gravenhorst, 1802) & - & - & 2 \\
\hline Ph. quisquiliarius (Gyllenhal, 1810) & - & - & 3 \\
\hline Ph. rectangulus Sharp, 1874 & - & - & 2 \\
\hline Ph. salinus Kiesenwetter, $1844^{*}$ & - & - & 2 \\
\hline Ph. spinipes Sharp, 1874 & - & 1 & - \\
\hline Ph. succicolla Thomson, 1860 & 1 & 1 & - \\
\hline Ph. tenuicornis Mulsant et Rey, 1853 & 2 & - & - \\
\hline Ph. varians (Paykull, 1789) & 1 & - & - \\
\hline Plathystethus cornutus (Gravenhorst, 1802) & - & - & 1 \\
\hline Plathystethus sp. & - & 1 & - \\
\hline Platydracus fulvipes (Scopoli, 1763) & 2 & - & - \\
\hline P. stercorarius (Olivier, 1795) & 2 & 2 & - \\
\hline Pseudomedon obscurellus (Erichson, 1840) & - & - & 3 \\
\hline Quedius fulgidus (Fabricius, 1793) & - & 1 & - \\
\hline Q. fuliginosus (Gravenhorst, 1802) & 1 & & 1 \\
\hline Q. invreae Gridelli, 1924* & 1 & - & - \\
\hline Quedius sp. & - & - & 1 \\
\hline Rabigus tenuis (Fabricius, 1792) & 1 & - & - \\
\hline Rybaxis longicornis (Leach, 1817) & - & 1 & - \\
\hline Rugilus rufipes (Germar, 1836 & 1 & - & - \\
\hline R. similis (Erichson, 1839) & - & - & 2 \\
\hline R. subtilis Erichson, 1840 & - & 2 & - \\
\hline Scopaeus debilis Hochhuth, 1851 & - & - & 2 \\
\hline S. laevigatus (Gyllenhal, 1827) & - & - & 1 \\
\hline Sepedophilus immaculatus (Stephens, 1832) & - & - & 2 \\
\hline S. marshami (Stephens, 1832)** & - & - & 1 \\
\hline S. testaceus (Fabricius, 1793) & 1 & 1 & - \\
\hline Sepedophilus sp. & 1 & 1 & 1 \\
\hline Staphylinus caesareus Cederhjelm, 1798 & 3 & 3 & 3 \\
\hline S. erythropterus Linnaeus, 1758 & 2 & 1 & 2 \\
\hline Stenus clavicornis Scopoli, 1763 & - & 1 & 2 \\
\hline S. humilis Erichson, 1839 & - & - & 1 \\
\hline Stenus sp. & 1 & 1 & 1 \\
\hline Sunius melanocephalus (Fabricius, 1792) & 1 & 1 & - \\
\hline Tachinus laticollis Gravenhorst, 1802 & 2 & - & - \\
\hline T. rufipes (De Geer, 1774) & 2 & - & 1 \\
\hline Tachyporus abdominalis (Fabricius, 1781) & 2 & - & - \\
\hline T. hypnorum (Fabricius, 1775) & 2 & 2 & 2 \\
\hline T. nitidulus Fabricius 1781 & 1 & 2 & - \\
\hline T. scitulus Erichson, 1839 & - & 1 & \\
\hline T. solutus Erichson, 1839 & & 1 & 1 \\
\hline Tachyusa nitidula Mulsant \& Rey, $1875^{* *}$ & - & - & 1 \\
\hline Tasgius globulifer (Fourcroy, 1785) & - & 1 & 2 \\
\hline T. melanarius (Heer, 1839) & 2 & 2 & - \\
\hline T. pedator (Gravenhorst, 1802)* & - & 1 & - \\
\hline Tasgius sp. & 1 & 1 & - \\
\hline Tetartopeus terminatum (Gravenhorst, 1802) & - & - & 1 \\
\hline Xantholinus dvoraki Coiffait, 1956 & 1 & - & - \\
\hline X. gallicus Coiffait, 1956* & 1 & - & - \\
\hline
\end{tabular}

\begin{tabular}{lccc}
\hline \multicolumn{1}{c}{ Genera, species } & Kyiv & Kharkiv & Dnipro \\
\hline X. laevigatus Jacobsen, 1849 & 1 & - & - \\
X. longiventris Heer, 1839 & - & 2 & 3 \\
X. tricolor (Fabricius, 1787) & 1 & 1 & - \\
Xantholinus sp. & - & - & 1 \\
Zyras funestus (Gravenhorst, 1806) & 1 & 2 & \\
Z. lugens Gravenhorst, 1802 & - & 2 & \\
\multicolumn{1}{c}{ Total/common } & $68 / 20$ & $68 / 18$ & $67 / 28$ \\
\hline
\end{tabular}

Note: * the species is reported for Ukraine in the both editions of the catalogues of staphylinids of the Palearctic (Smetana, 2004; Schülke \& Smetana, 2015); ${ }^{* *}$ - species is not reported for Ukraine in the first edition of the catalogue of staphylinids of the Palearctic (Smetana, 2004).

Discoveries of some species of staphylinids were interesting in faunistic aspect. In the first edition of the Catalogue of Palearctic Coleoptera (Smetana, 2004), 16 species of Staphylinidae recorded in our study were not mentioned for Ukraine (Table 2). However, later data on some of these species were taken into account, and in the last catalogue of staphylinids of the Palearctic (Schülke \& Smetana, 2015), eight species remained unreported for Ukraine: Arpedium quadrum (Gravenhorst, 1806), Atheto laticeps (Thomson, 1856), Medon apicalis (Kraatz, 1857), Ocalea rivularis Muller, 1851, Philonthus salinus Kiesenwetter, 1844, Quedius invreae Gridelli, 1924, Tasgius pedator (Gravenhorst, 1802), Xantholinus gallicus Coiffait, 1956 (Table 1). This does not mean that they had not been reported for Ukraine earlier, but rather indicates that the authors of the catalogues made insufficient analysis of some of the literature sources, most of which were unfortunately published in limited regional editions (mainly abstracts of papers given at conferences in Ukrainian and Russian). Therefore, Philonthus salinus was reported for Zaporizhia Oblast (Velykyi Luh National Park), Arpedium quadrum, Ocalea rivularis, Quedius invreae and Xantholinus gallicus - for the outskirts of Kyiv, and Atheta laticeps for Dnipropetrovsk (Dnipro-Orel Nature Reserve and the outskirts of Dnipro) and Odessa (Tylyhulskyi Regional Landscape Park) oblasts (Nazarenko \& Petrenko, 2007; Faly et al., 2011, 2013; Faly \& Glotov, 2012). Their discovery was expected rather than surprising, because according to the recent catalogue (Schülke \& Smetana, 2015) they have been reported for practically all Ukraine's neighbouring countries - Hungary, Poland, Slovakia, Moldova and South European Russia. The records of Medon apicalis and Tasgius pedator can be considered new for Ukraine, though confirming the novelty of their discovery requires checking a number of regional lists of staphylinids (especially by a number of studies by A. A. Petrenko), as moreover they were also reported in most of Ukraine's neighbouring countries.

For the separate metropolises the species diversity was much lower, but the number of recorded species practically did not differ. In the epigeal habitat of urban cenoses of Kharkiv and Kyiv, 68 species were recorded in each (belonging to 44 and 38 genera respectively) and 67 (39 genera) in Dnipro (Table 1). Some differences were observed in the number of common species of staphylinids. The highest number was observed in Dnipro (28), whereas in the urban cenoses of Kyiv and Kharkiv their number was considerably lower -20 and 18 species respectively (Table 1). At the same time, among them, in all the metropolises, two species (Staphylinus caesareus and Drusilla canaliculata) should be identified to eudominants. In urban cenoses of Dnipro, the abundant species were also Philonthus intermedius and Xantholinus longiventris, and in Kharkiv and Kyiv Ocypus nitens. The dominants and subdominants were represented by 18 25 species. Almost two thirds of staphylinids of the cities were identified to rare and occasional elements.

Significant differences were seen in faunistic comparison of the staphylinid fauna of the different cities. The lowest similarity was observed between the populations of staphylinids of urban cenoses of Dnipro and those of Kyiv and Kharkiv ( $15.3 \%$ and $17.5 \%$ respectively according to Jaccard's coefficient). The similarity of the staphylinid faunas of Kyiv and Kharkiv was more than twice as high (36.0\%) as in the previous two pairs of cities. Such differences, seem to be due to geographic peculiarities of the regions - forest-steppe (Kyiv, Kharkiv) and steppe (Dnipro) zones, conditioning the distribution of one or the other species with different ecological characteristics and ranges. A similar pattern was seen when comparing only the common species. However, the parameters of similarity were higher, especially between the common staphylinids of Kyiv and Kharkiv (73.9\%). The level of similarity of Staphilini- 
dae of Dnipro with those of Kyiv and Kharkiv already equaled $28.2 \%$ and $37.1 \%$, i.e. was twice as high as in comparison of all the species of staphylinids. To a large extent this is due to the fact that the majority of common species are eurybionts or forest (in a broad sense) species, occurring in various biotopes over a large territory. Within the transformed biocoenoses an interesting fact is also that the faunistic specificity was seen in staphylinids of the urban territory and the neighbouring agrocenoses of field crops. Comparing our own data on fauna of staphylinids of urban cenoses of Dnipro with those of field crops of the North subzone of the steppe (Dnipropetrovsk oblast, Synelnykovsky district) according to the data of Sumarokov (2009), the faunistic similarity was low (around 30\%). Certain differences in species diversity and number of staphylinids were observed also in different biotopes of a single city. This can be seen especially clearly on the example of Kharkiv (Table 2,4$)$.

Table 2

Species composition and abundance of staphylinids in different urban cenoses of Kharkiv (mean for 2017-2019)

\begin{tabular}{|c|c|c|c|c|c|c|}
\hline Species & City parks & Forest-park & $\begin{array}{c}\text { Plantations } \\
\text { on the outskirts }\end{array}$ & $\begin{array}{l}\text { Plantations } \\
\text { in the center }\end{array}$ & $\begin{array}{c}\text { Area of } \\
\text { private housing }\end{array}$ & $\begin{array}{c}\text { Share of } \\
\text { the species, } \%\end{array}$ \\
\hline Aleochara bipustulata Linnaeus, 1760 & - & - & 1 & 1 & - & 0.13 \\
\hline A. laevigata Gyllenhal, 1810 & - & - & 2 & 1 & - & 0.32 \\
\hline Aleochara sp. & 1 & - & 1 & 1 & - & 0.13 \\
\hline Aleocharinae gen. sp. & 2 & 2 & 1 & 2 & 2 & 2.16 \\
\hline Anotylus insecatus Gravenhorst, 1806 & 1 & 1 & 1 & 2 & 2 & 2.23 \\
\hline A. imustus Graven, 1806 & 1 & - & 1 & - & - & 0.09 \\
\hline A. rugifrons Hochhuth, 1849 & 1 & 1 & 1 & 1 & - & 0.13 \\
\hline A. rugosus Fabricius, 1775 & 1 & - & - & - & - & 0.04 \\
\hline A. sculpturatus Gravenhorst, 1806 & 1 & 1 & - & 1 & 1 & 0.13 \\
\hline Astenus procerus Gravenhorst, 1806 & - & - & 1 & 1 & - & 0.09 \\
\hline Astrapaeus ulmi Rossi, 1790 & 1 & - & 1 & 1 & - & 0.13 \\
\hline Atheta sp. & 1 & 1 & & 1 & - & 0.16 \\
\hline Drusilla canaliculata Fabricius, 1787 & 2 & 1 & 3 & 3 & 3 & 23.87 \\
\hline Emus hirtus Linnaeus, 1758 & - & - & 1 & - & - & 0.04 \\
\hline Gabrius osseticus Kolenati, 1846 & 1 & 1 & 2 & 2 & - & 0.78 \\
\hline Gabronthus thermarum Aubé, 1850 & - & - & 2 & 1 & - & 0.23 \\
\hline Gauropterus fulgidus (Fabricius, 1787) & - & - & - & - & 1 & 0.04 \\
\hline Gyrohypnus sp. & - & - & - & - & 1 & 0.04 \\
\hline Heterothops sp. & - & - & 1 & 1 & - & 0.09 \\
\hline Ichnosoma sp. & - & - & 1 & 1 & - & 0.09 \\
\hline Lathrobium brunnipes (Fabricius, 1792) & - & 1 & - & - & - & 0.04 \\
\hline Leptiphius flavocinctus Hochhuth, 1849 & 1 & - & - & 1 & - & 0.19 \\
\hline Mycetophorus sp. & - & - & - & 1 & - & 0.04 \\
\hline Ocypus brunnipes Fabricius, 1781 & 1 & 2 & 2 & 1 & 1 & 1.04 \\
\hline O. nitens Schrank, 1781 & 1 & 2 & 2 & 3 & 2 & 5.93 \\
\hline O. picipennis Fabricius, 1781 & 1 & 1 & - & - & - & 0.16 \\
\hline Olophrum assimile Paykull, 1800 & 1 & 2 & 1 & 1 & 1 & 0.55 \\
\hline Omalium rivulare Paykull, 1789 & 2 & 1 & 1 & 1 & - & 0.55 \\
\hline Omalium sp. & - & - & - & 1 & - & 0.16 \\
\hline Ontholestes murinus Linnaeus, 1758 & 1 & 1 & - & - & 1 & 0.09 \\
\hline Othius punctulatus (Goeze, 1777) & 1 & - & - & - & - & 0.04 \\
\hline Oxypoda sp. & 1 & - & 1 & 2 & 1 & 0.58 \\
\hline Paederus fuscipes Curtis, 1826 & 1 & 1 & - & - & - & 0.13 \\
\hline P. littoralis Gravenhorst, 1802 & - & - & 1 & 1 & - & 0.07 \\
\hline Philonthus carbonarius Gravenhorst, 1802 & 1 & 1 & 1 & 1 & 1 & 0.26 \\
\hline P. cognatus Stephens, 1832 & - & 1 & - & 1 & - & 0.07 \\
\hline P. decorus Gravenhorst, 1802 & 2 & 2 & 1 & 1 & 1 & 1.77 \\
\hline P. lepidus Gravenhorst, 1802 & - & - & 1 & 1 & - & 0.26 \\
\hline P. politus Linnaeus, 1758 & 1 & - & 1 & - & - & 0.07 \\
\hline P. spinipes Sharp, 1874 & - & - & - & - & 1 & 0.04 \\
\hline P. succicola Thomson, 1860 & 1 & - & - & - & 1 & 0.09 \\
\hline Plathystethus sp. & - & - & & 1 & - & 0.07 \\
\hline Platydracus stercorarius Olivier, 1795 & 1 & 1 & 1 & 2 & 1 & 0.46 \\
\hline Rugilus subtilis Erichson, 1840 & 1 & 2 & 1 & 2 & 1 & 1.21 \\
\hline Sepedophilus testaceus (Fabricius, 1793) & 1 & 1 & 1 & 1 & - & 0.13 \\
\hline Staphylinus caesareus Cederhjem, 1798 & 3 & 3 & 1 & - & 1 & 46.69 \\
\hline S. erythropterus Linnaeus, 1758 & 1 & 1 & - & - & - & 0.19 \\
\hline Stenus clavicornis Scopoli, 1763 & 1 & 1 & 1 & 1 & - & 0.23 \\
\hline Stenus sp. & - & - & 1 & - & - & 0.04 \\
\hline Sunius melanocephalus Fabricius, 1793 & - & - & 1 & - & - & 0.04 \\
\hline Tachyporus hypnorum Fabricius, 1775 & 1 & - & 2 & 1 & 1 & 0.23 \\
\hline T. nitidulus Fabricius, 1781 & 1 & - & 1 & 2 & - & 0.78 \\
\hline T. scitulus Erichson, 1839 & - & - & 1 & - & - & 0.13 \\
\hline T. solutus Erichson, 1839 & - & - & 1 & 1 & - & 0.09 \\
\hline Tasgius melanarius Heer, 1839 & 1 & 1 & 2 & 1 & 1 & 0.62 \\
\hline Tasgius sp. & - & - & - & - & 1 & 0.04 \\
\hline Xantholinus longiventris Heer, 1839 & 2 & 1 & 2 & 2 & 2 & 2.91 \\
\hline X. tricolor (Fabricius, 1787) & - & - & - & 1 & - & 0.04 \\
\hline Zyras funestus Gravenhorst, 1806 & 1 & 1 & 2 & 2 & 1 & 1.35 \\
\hline Z. lugens Gravenhorst, 1802 & 1 & 1 & 1 & 2 & 1 & 1.67 \\
\hline Number of species: total / common & $37 / 7$ & $28 / 8$ & $40 / 11$ & $41 / 9$ & $24 / 7$ & $60 / 18 / 100.00 \%$ \\
\hline $\begin{array}{l}\text { Average dynamic density of staphylinids (for } 10 \text { trap-days/for } \\
\text { season) / overall number of the recorded beetles (spec.) }\end{array}$ & $4.24 / 1424$ & $4.01 / 1372$ & $0.91 / 340$ & $2.73 / 919$ & $0.45 / 101$ & $12.27 / 4156$ \\
\hline
\end{tabular}


Table 3

Jaccard index of faunistic similarity of (\%, upper right comer of the table) and number of species of staphylinid communities which were common for different urban cenoses of Kharkiv (lower left corner) (data for 2017-2018)

\begin{tabular}{lccccc}
\hline \multicolumn{1}{c}{ Urban cenoses } & City parks & Forest-park & Plantations on outskirts & Plantations in the center & Area of private housing \\
\hline City parks & - & 66.7 & 51.0 & 52.9 & 46.7 \\
Forest-park & 26 & - & 41.7 & 68.8 & -18.6 \\
Plantation on outskirts & 26 & 20 & - & 33 & 17 \\
Plantations in center & 27 & 17 & 17 & 36.2 \\
Area of private housing & 20 & & - & 17 \\
\hline
\end{tabular}

Table 4

Ecological characteristic of common species of staphylinids in urban cenoses of Kharkiv (data for 2017-2019)

\begin{tabular}{|c|c|c|c|c|c|}
\hline Species & Habitat specialisation & Thermal preferendum & Trophic characteristic & Hygro-preferendum & Share of species $(\%)$ in different urban cenoses \\
\hline Aleochara laevigata & $\mathrm{pt}$ & mstp & zp & mshp & $0.10-0.57$ \\
\hline Anotylus insecatus & $\mathrm{pt}$ & oltp & zsp & hgp & $2.12-3.63$ \\
\hline Drusilla canaliculata & $\mathrm{pt}$ & mstp & zp & mshp & $10.63-45.60$ \\
\hline Gabrius osseticus & $\mathrm{pt}$ & mstp & zp & mshp & $0.11-1.24$ \\
\hline Ocypus brunnipes & $\mathrm{pt}$ & mgtp & zp & mshp & $1.04-3.25$ \\
\hline O. nitens & $\mathrm{pt}$ & mgtp & zp & mshp & $0.45-5.94$ \\
\hline Olophrum assimile & $\mathrm{pt}$ & олмф & zpp & hgp & $0.14-0.68$ \\
\hline Omalium rivulare & $\mathrm{pt}$ & олмф & zpp & hgp & $0.28-0.75$ \\
\hline Philonthus decorus & fr & mgtp & $\mathrm{zp}$ & mshp & $0.24-2.36$ \\
\hline Platydracus stercorarius & $\mathrm{pt}$ & mstp & zp & msp & $0.10-0.52$ \\
\hline Rugilus subtilis & $\mathrm{pt}$ & mgtp & zp & $\operatorname{mshp}$ & $0.11-2.24$ \\
\hline Staphylinus caesareus & fr & mstp & zp & mshp & $1.92-47.50$ \\
\hline Tachyporus hypnorum & $\mathrm{pt}$ & oltp & zp & msp & $0.12-0.58$ \\
\hline T. nitidulus & fr-md & oltp & zp & hgp & $0.10-0.95$ \\
\hline Tasgius melanarius & $\mathrm{pt}$ & mstp & zp & $\operatorname{mshp}$ & $0.32-0.64$ \\
\hline Xantholinus longiventris & fr-sh & mgtp & zp & hgp & $0.95-4.83$ \\
\hline Zyras funestus & md-fr & mstp & zp & msp & $0.18-2.21$ \\
\hline Z. lugens & fr-md & mstp & zp & msp & $0.10-3.12$ \\
\hline
\end{tabular}

Note: biotopic confinedness: $\mathrm{pt}$ - polytopic, fr - forest, bu - shrub, md - meadow species; thermal preferendum: mstp - mesothermophilous, oltp - oligothermophilous, mgtp megathermophylous; trophic characteristic: zp - zoophagous (carnivorous), zsp - zoosaprophagous, zpp - zoophytophagous; hygro-preferendum: msp - mesophilous, mshp mesohygrophilous, hgp-hygrophilous.

At the same time, the bulk of the attention was paid to the common species, but taking into account certain differences in the staphylinid fauna of different urban cenoses due to species seen on separate plots on singular occasions (and that is with regard to no less than two thirds of the fauna).

The lowest diversity and number of rove beetles were observed in the areas of private housing ( 24 species, 0.45 spec./10 traps over season). Seven species were recorded as common, among which Drusilla canaliculata was the dominant species, and Anotylus insecatus, Ocypus nitens and Xantholinus longiventris were identified to subdominants. Staphylind fauna of the Forest-park was represented by 28 species (including 8 common), but their dynamic density was significantly lower (4.01 spec./ 10 traps over season). The only dominant species was Staphylinus caesareus, and Tasgius melanarius and Philonthus decorus were recorded as common. The richest fauna in taxonomical aspect was the one in the green plantations of the outskirts (40) and the center of city (41 species) and the abundance was comparatively average, comprising $0.91-2.73$ spec. $/ 10$ traps over the season. Nine and eleven species respectively were identified as common. Eudominant everywhere was also Drusilla canaliculata, but Anotylus insecatus, Gabrius osseticus, Ocypus brunnipes, Ocypus nitens and Zyras funestus were common. Subdominants were represented by Aleochara laevigata, Platydracus stercorarius, Rugilus subtilis, Xantholinus longiventris and Zyras lugens. Among staphylinids of the city parks, 37 species were recorded (including only seven common) and quantitatively they exceeded the number caught in other urban cenoses (4.24 spec./10 traps over season). Here, similarly to the Forest-park, the only dominant was Staphylinus caesareus, and Drusilla canaliculata, Omalium rivulare, Philonthus decorus, and Xantholinus longiventris were common. A certain specificity of the fauna and different numbers of staphylinid species in separate parks within one city (Leipzig, Germany) were noted in the studies by Klausnitzer et al. $(1980,1982)$, Klausnitzer $(1986,1990)$. Therefore, in large and densely wooded plantations of Kharkiv, large species of staphylinids dominated, representing mainly typical forest epigean species, and small species (mainly hypogean beetles) occurred in lower numbers. At the same time, the abundance among all of staphylinds was comparatively low (less than 40-50\%).

The number and abundance of staphylinids in the center and outskirts of the megalopolis were high only in separate "refugia" - specific green "islands" in the territory of the city, small plots of green plantations (in this case - territory of Forerstry Institute and Botanical Garden of the KNPU), almost not trampled and mowed, but having been irregularly watered) compared with city's typical green lawns or garden squares actively visited by the population. A number of counts performed on typical open lawns and in garden squares showed the extreme poverty of the staphylinid fauna (2-4 species) and their very low number (no more than 0.2 spec./trap-days). In this case, we observed a significant aggregativeness (up to 80-90\%) of species in plantations of both the city center and the outskirts of the city, i.e. very high in some small urban cenoses (with favourable microhygrothermal regime) and extremely low - in other areas affected by intense anthropogenic pressure (mainly by trampling which causes significant compaction and dessication of the soil). Low values of the diversity and dynamic density of staphylinids in areas of private housing also could be due to the agricultural activity - constant cultivation and digging of soil, use of fertilizers and insecticidal treatments.

The data we obtained on the diversity and abundance of the fauna of staphylinids at the level of genera, especially in the parks, were close to that for other cities of Central and Eastern Europe (Klausnitzer et al., 1982; Klausnitzer, 1990; Molodova, 1991; Halinouski, 2006; Nazarenko \& Petrenko, 2007; Shulaev \& Bogdanov, 2008). At the same time, the peculiarities of the taxonomic composition and number of staphylinids in different city areas caused the comparatively high parameters of their faunistic similarity (Jaccard coefficients ranged within $35.4-68.8 \%$, Fig. 1). The lowest faunistic similarity was observed for the comparison of the plantations of the center and the periphery of the city with that of areas of private housing (35.4-36.2\%). Maximum similarity was observed when comparing the species composition of staphylinids in the plantations of the center and the outskirts $(68.0 \%)$, and also a large city park and the Forest-park $(66.7 \%)$. Similarity of the fauna of staphylinids of green areas of the outskirts and the center with the parks and forest countryside plots were average (41.7-51.0\%, Fig. 1). These parameters can indicate the confinedness of some species of staphylinids to particular urbanized areas.

The range of ecological groups of common species of staphylinids of Kharkiv was quite poor (Table 4), but their quantitative characteristic can to some extent explain the peculiarities of abundance and faunistic similarity of staphylinids in different megalopolises. In terms of biotopic confi- 
nedness, in most biocoenoses the polytopic elements dominated (over two thirds of species in some biotopes - up to $80-90 \%$ of the number of the family). The quantitative share of forest (Philonthus decorus, Staphylinus caesareus), and forest-meadow and meadow-forest (Xantholinus longiventris, species of Zyras genus) species sometimes accounted for half of the staphylind fauna, but only in the parks and suburban forest. Regarding the diet, as well as diversity and number, the typical carnivorous dominated. Zoosaprophagous (Anotylus insecatus) and zoophytophagous (Olophrum assimile, Omalium rivulare) were represented mainly by subdominant species.

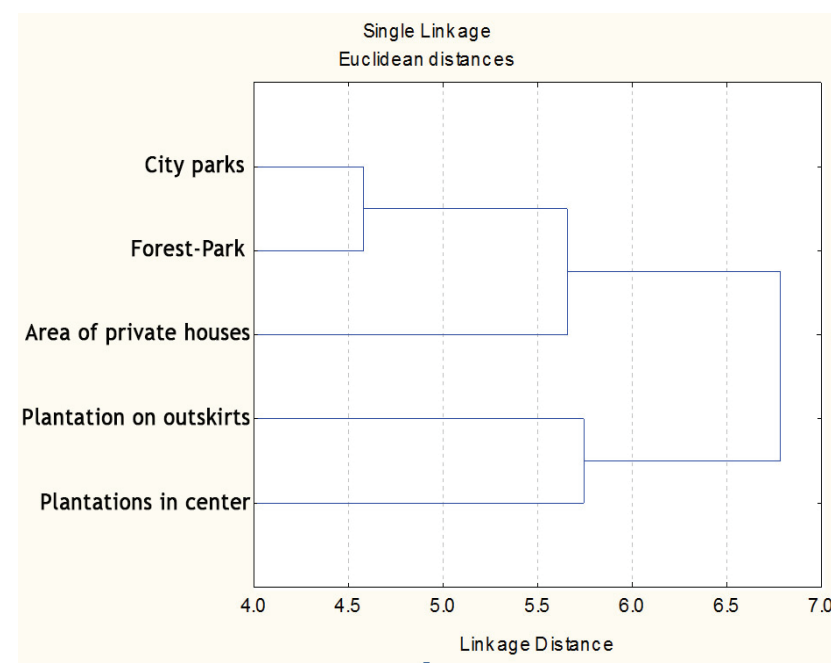

Fig. 1. Dendogram of faunistic similarity of staphylinids of the main urban cenoses of Kharkiv

Staphylinids are also hard to describe regarding the hygrothermal preferendum, as the temperature and moisture in the litter and cracks in the soil and other substrates where Staphylinidae live significantly differ from such for above-ground conditions (for example two meters above the soil surface). Therefore, distinguishing these groups in relation to temperature and moisture is to some extent subjective and based on the analysis of general microclimatic conditions of one or the other stage, but taking into consideration the available literature data on the impact of these ecological factors on rove beetles (Tikhomirova, 1973; Kanao et al., 2016; Betz et al., 2018). According to thermal preferendum, mesothermophilous dominated (over the half of the species, around $70 \%$ of the number, mainly Drusilla canaliculata, Gabrius osseticus, Staphylinus caesareus, species of Zyras genus). Conditional megathermophilous (species of Ocypus genus, Philonthus decorus, Rugilus subtilis, Xantholinus longiventris) accounted for 6-20\% of the number of staphylinids, especially in thinned-out areas. The share of four species of oligothermophyles (mainly Anotylus insecatus, Olophrum assimile and Omalium rivulare) did not exceed 5\% of number of Staphylinidae, and their abundance was low in most biocoenoses. By hygropreferendum, mesohygrophilous dominated everywhere (most species). Among hygrophilous, the common species were Anotylus insecatus and Xantholinus longiventris, whereas Olophrum assimile, Omalium rivulare, Tachyporus nitidulus and Tasgius melanarius were recorded as subdominants. Among the conditional mesophylous, species of Zyras genus were common and the number of others was no higher than $1-2 \%$ of the total number of the family.

As with the percentage, the share of different ecological groups for separate urban cenoses slightly differed from the total parameter for the city. Therefore, the main (but conditional) representatives of Staphylinidae in the epigeal habitat of the urban cenoses can be considered polytopic mesohygrophylous carnivorous, i.e. ecologically flexible species well adapted to the urban conditions.

The common species of staphylinids which live in the urban cenoses of Ukraine can be divided into two conditional groups (Tikhomirova, 1973; Bohač, 1985; Klauznitzer, 1990; Bohač, 1999):

- species which dominate in urban thinned-out plantations (both in center and in outskirts); they are mostly polytopic, represented by hypogean beetles and prefer more or less open ground, but are hardly affected by anthropogenic load (species of genera Anotylus, Drusilla, Gabrius, Rugi- lus, Zyras); many species are characterized by small sizes, fluctuations of number (low to very high), and also high migratory ability, allowing them to quickly inhabit new urban sites (i.e. they can be identified to species with r-strategy);

- species which dominate in typical tree biotopes (urban parks and the forest-park); are mainly forest (rarer polytopic) litter forms (species of genera Staphylinus, Ocypus and Philonthus), characterized by larger sizes, relatively constant life cycle, lower migratory activity and fertility (k-strategy).

\section{Conclusion}

Staphylinids of the epigeal fauna of Ukraine, despite their significant oligodominance, are characterized by rather rich diversity. In urban cenoses of Kyiv, Dnipro and Kharkiv, 140 species from 66 genera were recorded. Total of 69 (43 genera) were observed in Kyiv, 67 (39 genera) in Dnipro, 66 species (37 genera) in Kharkiv. In the latest catalogue of staphilinids of the Palearctic (Schülke \& Smetana, 2015), eight species found in our study had not been reported for Ukraine: Arpedium quadrum (Gravenhorst, 1806), Atheta laticeps (Thomson, 1856), Medon apicalis (Kraatz, 1857), Ocalea rivularis Muller, 1851, Philonthus salinus Kiesenwetter, 1844, Quedius invreae Gridelli, 1924, Tasgius pedator (Gravenhorst, 1802), Xantholinus gallicus Coiffait, 1956 (Table 1), despite being recorded in the country earlier.

By the number of common species, 29 were found in Dnipro, 21 and 19 species in Kyiv and Kharkiv respectively. At the same time (in all megalopolises), only two eudominant species were identified: Staphylinus caesareus and Drusilla canaliculata. Dominants and subdominants were represented by 18-25 species. Almost two thirds of the staphylinid fauna of cities was identified to rare species. While comparing the fauna of staphylinids of different cities, the lowest similarity was seen between population of urban cenoses of Dnipro and those in Kyiv and Kharkiv (15.3\% and $17.5 \%$ respectively by the Jaccard coefficient), whereas the similarity between Staphylinidae of Kyiv and Kharkiv was higher (36.0\%). Comparison of only common species showed higher parameters of faunistic similarity of the species: $73.9 \%$ for Kyiv and Kharkiv, and $28.2 \%$ and $37.1 \%$ for Dnipro and Kyiv and Dnipro and Kharkiv respectively.

The lowest diversity and abundance of staphylinids was seen in the area of private housing (24 species, 0.45 spec.). In the Forest-Park, 28 species were recorded. The richest fauna in taxonomic aspect was in the plantations of the outskirts (40) and center of the city (41 species). 37 species of staphylinids were recorded in the city parks. Faunistic similarity for different urban cenoses equaled $35.4-68.8 \%$. The lowest was revealed by comparison of plantations in the center and periphery of the city with those in the areas of private housing (35.4-36.2\%). Maximum parameters of similarity were observed between the areas of the center and outskirts of the city $(68.8 \%)$, and also large parks and the Forest-Park $(66.7 \%)$. Similarity of fauna of staphylinids of green areas of the outskirts and the center of the city with parks and forests in the outskirts was average (41.7-51.0\%).

By biotopic confinedness, in most of the urban cenoses, polytopic elements dominated, while forest and meadow-forest species dominated in parks. By thermopreferendum, mesothermophiles dominated (over the half of the species, around $70 \%$ of the number), and oligothermophyles were represented minimally. By trophic (both species composition and abundance) parameters, typical zoophages dominated, and zoosaprophages and zoophytophages were represented only by subdominant species. According to hygropreferendum, mesohygrophiles dominated everywhere. The observed differences are related to the diversity of the conditions in each separate urban cenoses (peculiarities of the vegetation and type of soil and density and mechanical composition, moisture, pattern of anthropogenic load), determining the structure of population of Staphylinidae.

The conducted research allowed us to analyze the staphylinid fauna of urban cenoses of three metropolises of Ukraine and evaluate their faunistic similarity and briefly characterize the ecological structure. A number of faunistic aspects of the family (peculiarities of formation of taxonomic structure, ecological preferendums of dominant species of staphylinids and spatial-temporal characteristic and biological peculiarities) nonetheless require elaboration. 
The authors express their sincere gratitude for the invaluable help in identifying many species of Staphylinidae and numerous consultations on the ecological characteristics of various staphylinids given by Candidate of Biological Sciences A. A. Petrenko (Schmallhausen Institute of Zoology of the Academy of Sciences of Ukraine, Kyiv) This work was supported by the Ministry of Education and Science of Ukraine (grant 0118U003303).

\section{References}

Betz, O., Irmler, U., \& Klimaszewski, J. (Eds.). (2018). Biology of rove beetles (Staphylinidae): Life history, evolution, ecology and distribution. Springer.

Bohac, J. (1999). Staphylinid beetles as bioindicators. Agriculture, Ecosystems and Environment, 74, 357-372.

Brygadyrenko, V. V. (2016). Influence of litter thickness on the structure of litter macrofauna of deciduous forests of Ukraine's steppe zone. Visnyk of Dnipropetrovsk University, Biology, Ecology, 24(1), 240-248.

Brygadyrenko, V. V., \& Korolev, O. V. (2015). Morphological polymorphism in an urban population of Pterostichus melanarius (Illiger, 1798) (Coleoptera, Carabidae). Graellsia, 71(1), e025.

Dekhtyareva, E. A. (2002). Pochvoobitajushchie vidy nasekomykh lesoparkov Kharkova kak component biocenoticheskogo kompleksa [Soil-dwelling insect species of Kharkov forest parks as a component of the biocenosis]. The Bulletin of V. V. Dokuchaev Kharkiv National Agrarian University, Series Biology, 3, 50-55 (in Russian).

Faly, L. I., \& Brygadyrenko, V. V. (2014). Patterns in the horizontal structure of litter invertebrate communities in windbreak plantations in the steppe zone of the Ukraine. Journal of Plant Protection Research, 54(4), 414420.

Faly, L. I., \& Glotov, S. V. (2012). Stafilinidy (Coleoptera, Staphylinidae) fauny balkovykh ecosystem mista Dnipropetrovs'k [Rove-beetles (Coleoptera, Staphylinidae) fauna of the cavins ecosystems of Dnepropetrovsk city]. Ecosystem dynamics: Proceedings of scientific conference. Lugansk. Pp. 2-3 (in Ukrainian).

Faly, L. I., Glotov, S. V., Kraynik, Y. M., \& Yakimets, K. G. (2013). Do vyvchennia zhukiv-stafilinid (Coleoptera, Staphylinidae) Dniprovs'ko-Orilis'kogo pryrodnogo zapovidnyka [On the studying of rove-beetles (Coleoptera, Staphylinidae) of the Dnieper-Oryl' Nature Reserve]. Biodiversity and importance of the animals in ecosystems: Proceedings of Scientific Conference. Adverta, Dnipropetrovsk. P. 175 (in Ukrainan).

Faly, L. I., Kolombar, T. M., Prokopenko, E. V., Pakhomov, O. Y., \& Brygadyrenko, V. V. (2017). Structure of litter macrofauna communities in poplar plantations in an urban ecosystem in Ukraine. Biosystems Diversity, 25(1), 29-38.

Faly, L. I., Petrenko, A. A., Krainik, Y. M., \& Glotov, S. V. (2011). Do vyvchennia zhukiv stafilinid (Coleoptera, Staphylinidae) nacional'nogo pryrodnogo parky "Velykyi Lug" [For studying of rove-beetles (Coleoptera, Staphylinidae) of the "Velikyi Lug" National Park]. Bioriznomanittia ta rol' tvaryn v ekosystemakh: Proceedings of Scientific Conference. DNU, Dnipropetrovsk. Pp. 223-224 (in Ukranian).

Fedyay, I. A., Markina, T. Y., \& Putchkov, A. V. (2018). Ecological and faunistic survey of the true bugs of the infraorder Pentatomomorpha (Hemiptera) in the urban cenoses of Kharkiv City (Ukraine). Biosystems Diversity, 26(4), 263-268.

Frank, J. H., \& Ahn, K.-J. (2011). Coastal Staphylinidae (Coleoptera): A worldwide checklist, biogeography and natural history. Zookeys, 107, 1-98.

Franzen, B. (1992a). Untersuchungen zur Käferfauna an ausgewählten Standorten in Köln (Insecta: Coleoptera). Decheniana, 150, 181-216.

Franzen, B. (1992b). Vorläufige Liste der Käfer von Köln (Insecta: Coleoptera). Decheniana, 150, 217-249.

Grebennikov, K. A., \& Anikin, V. V. (2015). Biotopicheskoe raspredelenie stafilinid Nizhney Volgi [Biotopical distribution of rove beetles (Coleoptera, Staphylinidae) of the lower Volga river]. Izvestiya of Saratov University, New Series Chemistry, Biology, Ecology, 15(3), 90-95 (in Russian).

Halinouski, N. H., \& Shauro, T. V. (2007). Vidovoy sostav i struktura gerpetobiontnykh zhestkokrylykh (Ectognatha, Coleoptera) zelenykh nasazhdeniy goroda Minska [The species composition and structure of the herpetobiontic Coleoptera (Ectognatha, Coleoptera) of the green zones of Minsk]. Transactions of Belarusian State Technological University, Seria Forestry, 15, 333337 (in Russian).

Kanao, T., Eldredge, K. T., \& Maruyama, M. (2016). A defensive body plan was pre-adaptive for termitophily in the rove beetle tribe Termitohospitini (Staphylinidae: Aleocharinae). Biorxiv.
Klausnitzer, B. (1986). Zum Inselcharakter stadtischer Grunraume. Wissenschaftliche Zeitschrift der Karl-Marx-Universitat Leipzig, MathematischNaturwissenschaftliche Reihe, 35(6), 593-606.

Klausnitzer, B., Köberlein, C., Köberlein, F., Vogel, J., \& Uhlig, M. (1982). Zur Staphylinidenfauna zweier Leipziger Stadtparks. Faunistische Abhandlungen Staatliches Museum fur Tierkunde Dresden, 18, 195-202.

Klausnitzer, B., Richter, K., \& Lehneert, J. (1980). Zur Insectenfauna der Parkanlage am Schwanenteich im Zentrum von Leipzig. Hercynia, 16, 213-224.

Klauznitzer, B. (1990). Ekologiya gorodskoy fauny [Ecology of the urban fauna]. Mir, Moscow (in Russian)

Komaromi, N. A., Nikolenko, N. Y., \& Puchkov, A. V. (2018). The faunistic structure of the beetles (Insecta: Coleoptera) in herpetobios of urbocenosis of Kharkov. Ukrainian Entomological Journal, 15, 3-21 (in Russian).

Lutska, M. P. (2019). Ecological and zoogeographical groups of rove beetles (Staphylinidae, Coleoptera, Insecta) of subalpine belt of northeastern macroslope of Ukrainian Carpathians. Studia Biologica, 13(1), 107-116.

Magura, T., Nagy, D., \& Tóthmérész, B. (2013). Rove beetles respond heterogeneously to urbanization. Journal of Insect Conservation, 17(4), 715-724.

Molodova, L. P. (1991). Kolichestvennaya i kachestvennaya kharakteristika zhukov gerpetobiontov v rayone krupnogo promyshlennogo obyedineniya v Gomele [Quantitative and qualitative characteristics of herpetobiont beetles in the region of a large industrial association in Gomel]. Fauna and ecology of the beetles in Belarus. Science and Technology, Minsk. Pp. 185-192 (in Russian).

Nasira, S., Akramb, W., \& Ahmedb, F. (2012). The population dynamics, ecological and seasonal activity of Paederus fuscipes Curtis (Staphylinidae; Coleoptera) in the Punjab, Pakistan. APCBEE Procedia, 4, 36- 41.

Nazarenko, V. Y., \& Petrenko, A. A. (2007). Do vyvchennia fauny zhukiv (Insecta: Coleoptera) Lysoyi Gory (Kyiv) [On the study of beetle fauna (Insecta: Coleoptera) of Lysa gora (Kyiv)]. The Kharkov Entomological Society Gazette, 15(12), $43-48$ (in Ukrainian).

Parmain, G., Bouget, C., Müller, J., Horak, J., Gossner, M. M., Lachat, T., \& Isacsson, G. (2015). Can rove beetles (Staphylinidae) be excluded in studies focusing on saproxylic beetles in central European beech forests? Bulletin of Entomological Research, 105, 101-109.

Petrenko, A. A. (2005). Do vyvchennia pryberezhnykh stafilinid (Coleoptera, Staphylinidae) ozer ta stavkiv mista Kyeva [To the studying of the shorelinel rovebeetles (Coleoptera, Staphylinidae) of the lakes and ponds in Kyiv]. Ecological status of reservoirs in Kyiv. Phyto-Bio Center, Kyiv. Pp. 75-87 (in Ukrainian).

Puchkov, A. V., \& Komaromi, N. A. (2018). Zhuky-karapuziki (Coleoptera, Histeridae) urbocenoziv Kharkova [The clown beetles (Coleoptera, Histeridae) of the urbocenosis of Kharkiv city (Ukraine)]. Biology and Valeology, 20, 54-58 (in Ukrainian).

Putchkov, A. V., Brygadyrenko, V. V., \& Markina, T. Y. (2019). Ground beetles of the tribe Carabini (Coleoptera, Carabidae) in the main megapolises of Ukraine. Vestnik Zoologii, 53(1), 3-12.

Putchkov, A. V., Markina, T. Y., \& Komaromi, N. (2017). Ecologo-faunistic review of lamellicom beetles (Coleoptera, Scarabaeoidea) of urbocenozis of Kharkov city (Ukraine). Biosystems Diversity, 25(4), 263-267.

Salnitska, M., \& Solodovnikov, A. (2019). Rove beetles of the genus Quedius (Coleoptera, Staphylinidae) of Russia: A key to species and annotated Catalogue. Zookeys, 847, 1-100.

Schülke, M., \& Smetana, A. (2015). Staphylinidae. In: Löbl, I., \& Löbl, D. (Eds.). Catalogue of Palaearctic Coleoptera. Vol. 2. Revised and updated version. Hydrophiloidea-Staphylinoidea. Brill, Leiden-Boston. Pp. 303-1134.

Shulaev, A. V., \& Bogdanov, A. V. (2008). K faune zhukov-stafilinid (Coleoptera, Staphylinidae) goroda Kazani [Fauna of rower-beetles (Coleoptera, Staphylinidae) of Kazan city]. The Bulletin of Kazan State University, 150(1), 121-125 (in Russian).

Smetana, A. (2004). Staphylinidae. In: Löbl, I., \& Smetana, A. (Eds.). Catalogue of Palaearctic Coleoptera. Vol. 2. Polyphaga, Hydrophiloidea - Staphylinoidea. Apollo Books, Stenstrup.

Sumarokov, A. M. (2009). Vosstanovleniye bioticheskogo potenciala biogeocenozov pri umen'shenii pesticidnykh nagnuzok [Restoring of the biotic potential of biogeocenosis while reducing pesticides press]. Weber, Donetsk (in Russian).

Tikhomirova, A. L. (1973). Morfologicheskie osobennosti i filogenez stafilinid (s katalogom fauny SSSR i sopredel'nykh territoriy) [Morphological and ecological features and phylogenesis of staphylinids (with a catalogue of USSR and adjacent territories)]. Nauka, Moscow (in Russian). 